\title{
EFFICIENCY OF BREATHING EXERCISES USED IN PHYSICAL THERAPY FOR 6-12-YEAR-OLD ASTHMATIC CHILDREN'S RESPIRATORY FUNCTION
}

\author{
Vytautas Karuža, Eglė Lendraitienė \\ Lithuania University of Health Sciences, Kaunas, Lithuania
}

\begin{abstract}
Background. The aim of the study was to assess the efficiency of breathing exercises for 6-12-year-old asthmatic children's respiratory function.

Methods. The study involved 15 children, 9 boys (60\%) and 6 girls (40\%). The average age of all subjects was $9.07 \pm 1.94$ years. Boys' average age was $8.89 \pm 1.90$ years, and that of the girls $-8.33 \pm 2.16$ years. All subjects participated in physical therapy were breathing exercises were applied for four weeks, 30-45 minutes per day. Moreover, before and after treatment with breathing exercises they had Stange and Henci tests (samples of breathing); breathing muscle strength test with pneumotonometer and abdominal muscle endurance test.

Results. After four weeks of physical therapy, the mean respiratory arrest inhalation statistically significantly increased by $11.16 \%,(p<.05)$. Exhaled breath with hold was $19.17 \%$ of the average change, but this change was not statistically significant $(p>.05)$; inspiration pressure changed by $27.30 \%$ on average $(p<.05)$; static abdominal muscle endurance significantly increased from 26.33 to $36.13 \%$; right side muscle static endurance significantly increased by $31.78 \%$ and left side static muscle endurance changed by $19.43 \%$.

Conclusion. Breathing exercises applied for four weeks for children aged 6-12 years, suffering from bronchial asthma, are useful for increasing respiratory arrest aspiration, inspiration and expiratory pressure, and the abdomen, trunk muscle endurance, but they do not result in any changes in respiratory arrest exhaled.
\end{abstract}

Keywords: breathing exercises, physical therapy, bronchial asthma, respiratory function.

\section{INTRODUCTION}

$\mathrm{B}$ ronchial asthma (BA) is one of the most common dysfunctions of the respiratory system. BA is a common chronic inflammatory disease that affects 235 million people around the world, which is the cause of frequent hospitalization (Ang et al. 2016). Moreover, on average, a quarter of the 40 million Americans suffering from asthma are children till 18 years old. Despite high numbers of patients, 4.1 million suffered from an asthma attack or episode (American Lung Association, 2011; Centers for Disease Control and Prevention, 2014). Children mortality related to asthma is associated with the inability to timely detection of the disease and preventive, lack of preventive measures (National centre for health statistics, 2014).
According to the latest World Health Organization (2014), data bronchial asthma is common worldwide disease, only in Europe $8-10 \%$ of population are suffering from asthma. Asthma is an inflammatory disorder with airway hyper responsiveness leading to recurrent episodes of wheezing, breathlessness, chest tightness and coughing, especially during the night and the early morning

Blažienė, Dubakienė, and Ėmužytė (2001), Bojarskis, Dubakienè, Ėmužytė, Kudzytė, and Valiulis (2002), Kudzytė, Griška, and Bojarskas (2008), and Valiulis, Bojarskas, and Ėmužytè (2005) note that approach to bronchial asthma classification, diagnosis, formulation, treatment and prevention were formed long time ago. 
However, the current science considers asthma as a disease and offers treatment guidelines (Abramson, Puy, \& Weiner 2011; Barnes, 2010; Morris, 2010).

Studies show that pulmonary condition of asthmatic children engaged in continuous physical activity is much better because when exercising the lungs get more oxygen and the air is more easily inhaled and exhaled (Ahnert et al., 2010; Basso et al., 2010; Keraitè-Bliūdžiuvienè, 2005; Repšienè, 2006; Stankute, 2011)

Physical therapy treatment plan for bronchial asthma should include activities that increase the function of breathing, strengthen breathing muscles and increase common physical fitness (Sipavičianè \& Škikas, 2012).

\section{METHODS}

To examine the function of respiratory system we used samples and tests for the respiratory system: Stange (sample) test, Henci (sample) test, the maximum inspiration (PImax) and maximum expiratory (PEmax) pressure. Also we used abdominal muscle endurance and side back muscle endurance tests.

Stange test. This test is applied to evaluate the children's respiratory capacity (respiratory functional status). During the test, two or three times children were asked to breathe deeply the air through the nose and not to breathe as long as possible. After the first test, a 2-3-minute break was taken and then children were asked to do the same. Time was measured in seconds by a stopwatch.

Henci test also aims to assess the functional status of the respiratory system. Before the test children were asked to try to breathe deeply in and out, repeat that for 2-3 times and hold their breath. Time was measured in seconds by a stopwatch.

Pneumotonometer was used to evaluate respiratory muscle strength changes before and after breathing exercises. Respiratory muscle strength was measured with pneumotonometer by measuring the maximum inspiration (PImax) and maximum expiratory (PEmax) pressure. Duering the test the patient is asked to exhale maximally with lips pressed against the mouthpiece of the device and try to breathe hard, and with the maximum inhalation to try to exhale hard. The data were taken for analysis only when the patient inspired or breathed for at least 1-2 seconds (Enright \& Hyatt, 1987).

Abdominal muscle endurance test. In order to assess the effects of physical therapy, children suffering from bronchial asthma were tested for the respiratory function. Before the test, children were asked to sit down with a 90-degree angle between the torso and thigh, and the thigh and calf.

The side back muscle endurance test. Before the test children were asked to lie down on one side, the upper front leg and the lower elongated (step phase) of the upper arm hand resting on the opposite shoulder and the lower arm bent at right angles. The request was to lift the body off the floor and the hold this position for as long as possible. The assessment was performed for both sides (left and right) muscle strength. Time was measured in seconds by a stopwatch (Strand et al., 2014).

Statistical analysis was performed using SPSS 21.0 for Windows and Microsoft Office Excel 2010 computer programs. Quantitative variables were the arithmetic mean and standard deviation. The changes were assessed by calculating the percentage difference. Values at $p<.05$ were considered as statistically significant.

\section{RESULTS}

Prior to physical therapy for children suffering from bronchial asthma, respiratory arrest inhalation (Stange test) was average $-29.13 \pm 9.84 \mathrm{~s}$, and respiratory arrest Exhaled (Henci test) value was $11.84 \pm 6.16 \mathrm{~s}$. After four weeks of physical therapy respiratory arrest inhalation average statistically significantly increased by $11.16 \%$ and it was $32.38 \pm 12.19 \mathrm{~s}(p<.05)$. Exhaled breath hold changed by $19.17 \%$ and it was $14.11 \pm 5.02 \mathrm{~s}$, but this change was not statistically significant $(p>.05)$ (Figure 1).

Inspiration and expiratory pressure and maximum expiratory airflow velocity changes before and after physical therapy. The analysis of changes of expiratory and aspiratory pressures showed that after four weeks of physical therapy both inspiration and expiratory pressure values were statistically significantly higher than before physical therapy $(p<.05)$. Before expiratory pressure physiotherapy the average was $59.53 \pm$ $38.15 \mathrm{cmH}_{2} \mathrm{O}$, and after physical therapy exhalation pressure average increased by $26.99 \%$ and reached $75.60 \pm 34.96 \mathrm{cmH}_{2} \mathrm{O}$. The research starting point of inspiration pressure average was $63.73 \pm 21.20 \mathrm{cmH}_{2} \mathrm{O}$, and after physical therapy inspiration pressure changed by $27.30 \%$ and was $81.13 \pm 15.87 \mathrm{cmH}_{2} \mathrm{O}$ (Figure 2).

Abdominal and side torso muscle isometric endurance change before and after physical therapy. Prior to physical therapy children's 

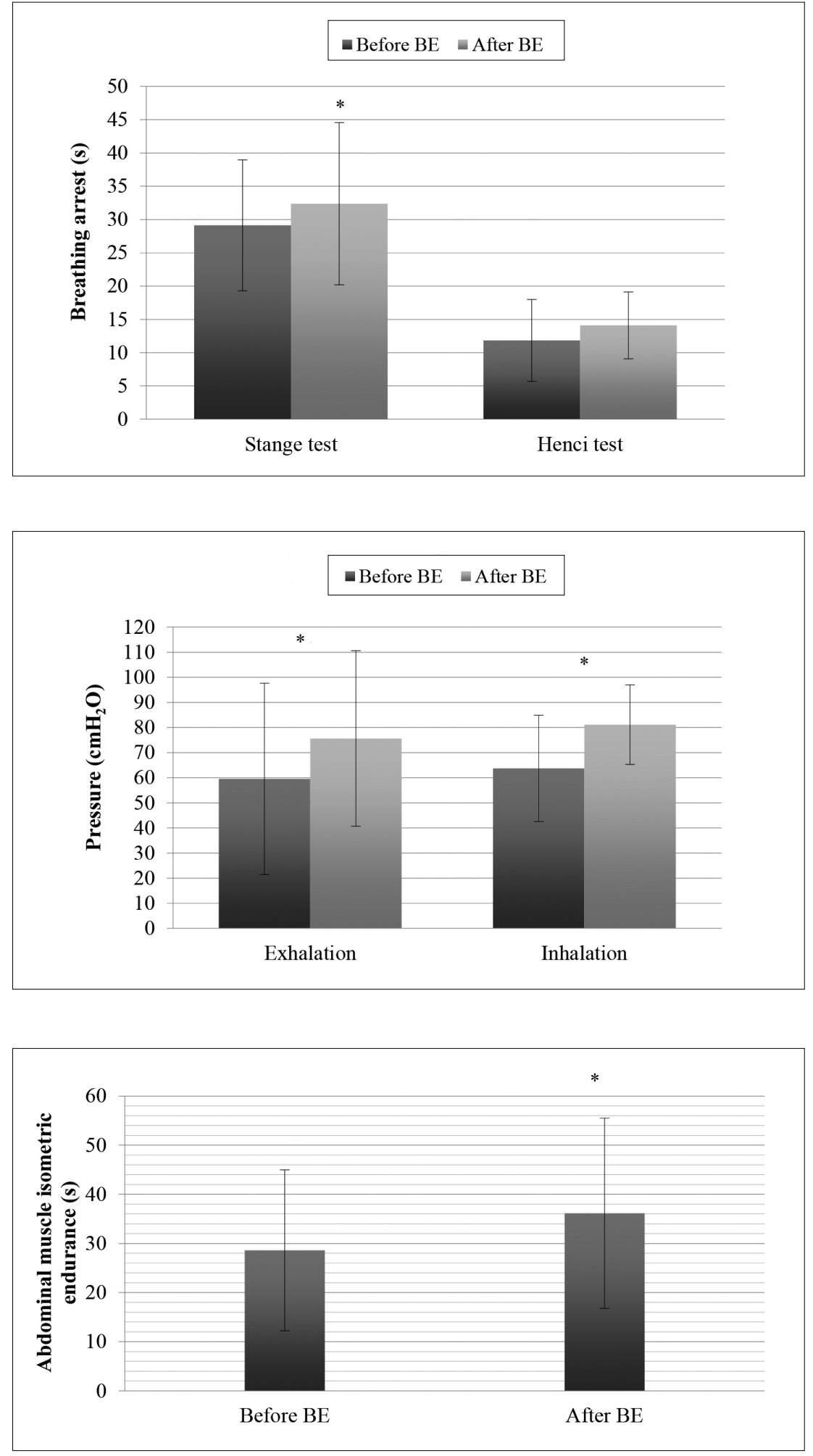

Figure 1. Respiratory arrest inhale and exhale changes before and after breathing exercises

Note. ${ }^{*} p<.05$ compared with the result before breathing exercises.

Figure 2. Expiration and inspiration pressure change before and after physical therapy

Note. ${ }^{*} p<.05$ compared with the result of physical therapy.

Figure 3. Abdominal muscle endurance change before and after physical therapy

Note. ${ }^{*} p<.05$ compared with the result of physical therapy.

suffering from bronchial asthma static abdominal muscle endurance average was $28.60 \pm 16.37$ seconds and after physical therapy static abdominal muscle endurance significantly increased by $26.33 \%$ to $36.13 \pm 19.38 \mathrm{~s}(p<.05)$ (Figure 3$)$.

The analysis of the lateral trunk muscle endurance change showed that after four weeks of physical therapy endurance averages were statistically significantly higher than those before physical therapy $(p<.05)$. Before physiotherapy, right side abdominal muscle endurance average was $39.68 \pm 21.21 \mathrm{~s}$ and after physical therapy this side muscle static endurance significantly increased by $31.78 \%$ and was $52.29 \pm 27.01 \mathrm{~s}$. The study in the initial point of the left-hand side of the torso muscle endurance average was $49.97 \pm 22.05 \mathrm{~s}$ and after physical therapy this side static muscle endurance changed by $19.43 \%$ and was $59.68 \pm 27.89 \mathrm{~s}$ (Figure 4). 


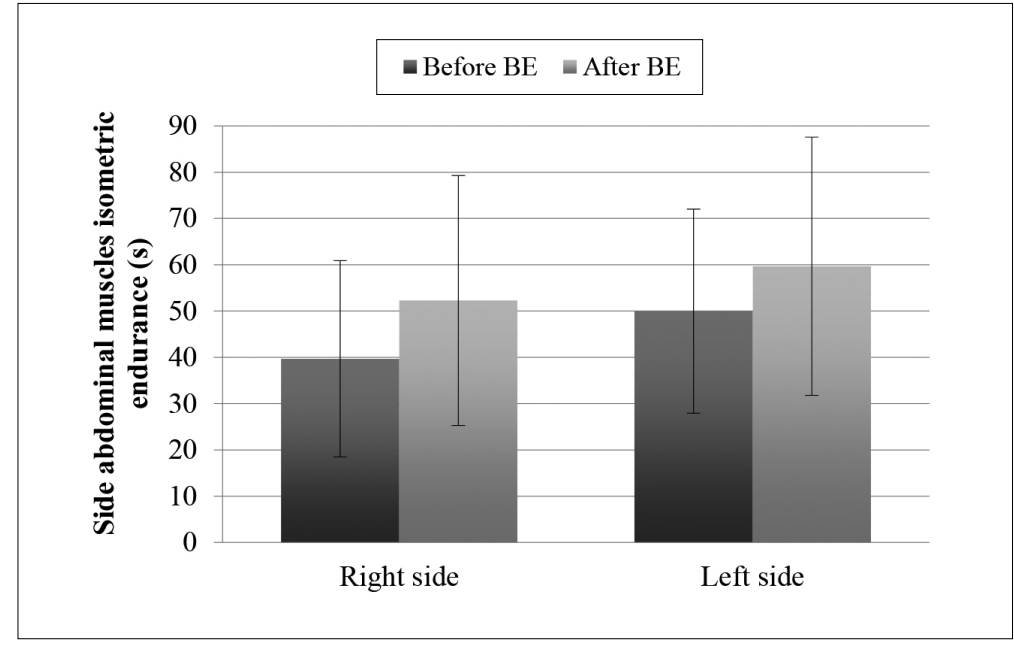

Figure 4. The side abdominal muscle endurance change before and after physical therapy

\section{DISCUSSION}

The aim of the present study was to investigate whether breathing exercises could play the main role in the treatment of patients with asthma. Our study dealt with the variability of breathing techniques. This study shows that breathing exercises can have beneficial effects in asthmatics. The main findings are that physiotherapy may improve not only the respiratory function, but also endurance of abdominal muscles.

In recent years, there were several significant physiotherapy achievements in the treatment of asthma in children (Ahnert et al., 2010; KeraiteBliūdžiuvienè, 2005; Repšienè, 2006; Stankutè, 2011), which proved that physical therapy effect was indeed positive and could significantly mitigate or in some cases, eventually even eliminate the symptoms. For example, research where 60 children received comprehensive rehabilitation (physical therapy, massage, halotherapy, physiotherapy) shows that forced expiratory volume in one second (FEV1), forced vital capacity indicators (FVC), forced expiratory ratio (FEV1 / FVC) and peak expiratory flow rate (PEF) after rehabilitation treatment statistically significant $(p<.05)$ improved as in this study, breathing exercises where helpful for changes in respiratory function.

Stange and Henci sample rehabilitation indicators treatment before and after the analysis showed that after rehabilitation, both the first and second group significantly $(p<.05)$ improved, but this improvement was more marked in individual physical therapy group. Results of this study show that Stange and Henci sample changes were not dependent on individual therapy. We can just see statistically significant changes in Stange sample in all groups.

None of the studies mentioned worsening of asthma symptoms following physical training.

\section{CONCLUSIONS}

Breathing exercises applied for four weeks for 6-12-year-old children suffering from bronchial asthma are useful as they increase respiratory arrest aspiration, inspiration and expiratory pressure, and the abdomen, trunk muscle endurance, but do not show any changes in respiratory arrest exhaled.

\section{REFERENCES}

Abramson, M. J., Puy, R. M., \& Weiner, J. M. (2010). Injection allergen immunotherapy for asthma. Cochrane Database Systematic Reviews, 4(8), CD001186.

Ahnert, J., Löffler, S., Müller, J., \& Vogel, H. (2010). Systematic literature review on interventions in rehabilitation for children and adolescents with asthma bronchiale. Rehabilitation, 49(3), 147-59.
American Lung Association. (2012). Trends in asthma morbidity and mortality. American Lung Association, Epidemiology and Statistics Unit Report. Retrieved from http://www.lung.org/assets/documents/research/ asthma-trend-report.pdf

Ang, Z. Y., Zhong, H. B, Mao, C., Yuan, J. Q., Huang, Y. F., Wu, X. Y.,..., Tang, J. L. (2016). Yoga for asthma. Retrieved from http://onlinelibrary.wiley.com. 
ezproxy.dbazes.lsmuni.lt:2048/doi/10.1002/14651858. CD010346.pub2/full

Barnes, P. J. (2010). New therapies for asthma: Is there any progress? Trends in Pharmacological Sciences, 31(7), 335-343. doi: 10.1016/j.tips.2010.04.009

Basso, R., Jamami, M., Pessoa, B.V., Labadessa, I. G., Regueiro, E. M. G., \& Di Lorenzo, V .A. P. (2010). Assessment of exercise capacity among asthmatic and healthy adolescents. Brazilian Journal of Physical Therapy, 14(3), 252-258.

Blažienė, A., Dubakienè, R., \& Ėmužytè, R. (2001). Vaiku bronchinès astmos diagnostika ir gydymas. Vilnius: Solidarity.

Bojarskis, J., Dubakienè, R., Ėmužytė, R., Kudzytė, J., \& Valiulis, A. (2002). Vaiku bronchu astmos diagnostika ir gydymas. Vaiku pulmonologija ir alergologija, T. 5, IV (1-2), 1762-1777.

Centers for Disease Control and Prevention. (2014). National Center for Health Statistics. CDC Wonder Online Database. Compiled from Compressed Mortality File 1999-2011 Series 20 No. 2Q.

Enright, P. L, \& Hyatt, R. E. (1987). Office spirometry. A practical guide to the selection and use of spirometers. Philadelphia: Lea \& Febiger.

Grinienė, E., \& Vaitkevičius, J. V. (2009). Vaiku ir paaugliu organizmo sistemogenezé. Kvépavimo sistemos funkciniai ypatumai. Šiauliai.

Keraitè-Bliudžiuvienė, K. (2005). Kineziterapijos efektyvumas, gydant bronchine astma sergančius 11-15 metu vaikus (Nepublikuotas magistro darbas). Kaunas: Lietuvos kūno kultūros akademija.
Kudzytė, J., Griška, E., \& Bojarskas, J. (2008). Vaikų bronchu astmos, alerginio rinito ir atopinio dermatito bei jiems būdingų simptomų paplitimo kaita tarp 6-7 metụ Kauno miesto moksleiviu (ISAAC tyrimo I ir III fazès rezultatai). Medicina, 44(12), 944-952.

Morris, K. J. (2010). Management of exercise-induced bronchospasm in adolescents with asthma. The Nurse Practitioner, 35(12), 18-26. doi: 10.1097/01

Repšienè, N. (2006). Grupinès ir individualios kineziterapijos efektyvumas, gydant 8-12 metu vaikus, sergančius bronchy astma (Nepublikuotas magistro darbas). Kaunas: Lietuvos kūno kultūros akademija.

Sipavičienè, S., \& Škikas, L. (2012). Širdies ir kraujagyslių bei kvẻpavimo sistemų funkcinès būklès tyrimo metodai. Kvépavimo sistemos funkcinès büklès tyrimas. Kaunas: LKKA. P. 59-80.

Smith, T., \& Rowley, J. (2011). Physical therapy reviews. Breathing pattern disorders and physiotherapy: Inspiration for our profession. Retrieved from http://web.ebscohost.com/ehost/pdfviewer/pdfviewer?sid=8cac5d51f801-4399-921f-9796981d243\%40sessionmgr13\&vid= $8 \&$ hid $=18$

Stankute, R. (2011). Tai Chi pratimu poveikis 8-11 metu vaikų, sergančiu bronchų astma, kvèpavimo funkcijai (Nepublikuotas magistro darbas). Kaunas: Lietuvos kūno kultūros akademija.

Strand, S. L, Hjelm, J., Shoepel, T. C., \& Fajardo, M. A. (2014). Norms for an Isometric Muscle Endurance Test. Journal of Human Kinetics, 40(1), 93-102. doi: 10.2478/ hukin-2014-0011

World Health Organization, WHO. (2014). Chronic respiratory diseases. Scope: Asthma. Retrieved from http://www.who.int/respiratory/asthma/scope/en/
Received on October 07, 2013

Accepted on November 21, 2016
Corresponding author Vytautas Karuža

Department of Rehabilitation

Lithuanian University of Health Sciences

Eivenių str. 2, LT-50009 Kaunas

Lithuania

E-mailkaruzav@gmail.com 